\title{
PKD1 wt Allele
}

National Cancer Institute

\section{Source}

National Cancer Institute. PKD1 wt Allele. NCI Thesaurus. Code C75895.

Human PKD1 wild-type allele is located in the vicinity of $16 \mathrm{p} 13.3$ and is approximately 47 $\mathrm{kb}$ in length. This allele, which encodes polycystin-1 protein, is involved in the development of the kidney. Mutations in the gene are associated with polycystic kidney disease autosomal dominant type 1 . 